
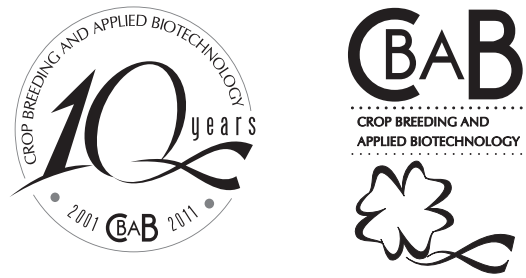

\title{
BRS Cipotânea and BRS Diamantina: maize varieties
}

\author{
Flavia França Teixeira ${ }^{1}$, , José Heitor de Vasconcellos ${ }^{1}$, Ramiro Vilela de Andrade ${ }^{1}$, Manoel Xavier dos Santos ${ }^{1}$, Carlos Eduardo Prado \\ Leite $^{1}$, Paulo Evaristo de Oliveira Guimarães ${ }^{1}$, Sidney Netto Parentoni ${ }^{1}$, Walter Fernandes Meirelles ${ }^{1}$, Cleso Antonio Patto Pacheco ${ }^{1}$ \\ and Gessi Ceccon ${ }^{2}$
}

Received 20 May 2010

Accepted 9 November 2010

ABSTRACT - The maize cultivars BRS Cipotânea and BRS Diamantina were developed from accessions of the Maize Germplasm Bank of Embrapa Maize and Sorghum. The evaluation was participative, performed by scientists and end-users. The varieties were developed to provide farmers with maize varieties suitable for corn-husk crafts.

Key words: handicraft; husk; Zea mays; participatory breeding; family farming.

\section{INTRODUCTION}

New high-yielding maize cultivars are made available to farmers by several breeding programs every year. The wide range of maize cultivars on the market is extremely favorable for Brazilian agriculture, because it leads to constant improvements in yield and quality (Ramalho et al. 2009). The main maize breeding goals focus on yield and yield-related factors, such as uniformity, stability and adaptability (Pacheco et al. 2002). Subsequently, breeding became a major driving force of the high increase of maize yield in Brazil. According to a survey released by the National Supply Company (CONAB 2010), the national maize yield of the first and second harvests together reached 54.14 million tons, representing a gain of $6.1 \%$ or 3.13 million tons, compared to the last period. Parallel to this promising scenario, the needs of some corn producers are not met by the cultivars available.

Farmers and artisans working with corn-husk handicraft need cultivars with long husks, in varying color and texture, according to the specific craft techniques. These producers, in general family farmers, claim that the cultivars available on the market do not adequately meet the requirements of corn husk craft (Teixeira et. al. 2005). To fill this gap in the range of cultivars available to Brazilian farmers, a participatory selection program was developed with accessions of the maize germplasm bank maintained by EMBRAPA that led to the indication of the maize varieties BRS Cipotânea and BRS Diamantina that have husk suited for crafting. The aim of this study was to inform the scientific community about aspects related to these cultivars.

\section{BREEDING METHODS}

\section{Plant material}

BRS Cipotânea and BRS Diamantina were used directly from the ex situ maize germplasm bank (information on the parents of these accessions in Table 1). These cultivars are open-pollinated varieties, which had to be

\footnotetext{
${ }^{1}$ Embrapa Milho e Sorgo, Rod. MG 424, km 65, 35.701-970, Sete Lagoas, MG, Brazil

${ }^{2}$ Embrapa Agropecuária Oeste, Rod. BR 163, km 256, 79.804-970, Dourados, MS, Brazil *E-mail: flavia@cnpms.embrapa.br
} 
Table 1. Information on the accessions of the maize germplasm bank used as parents of the varieties BRS Cipotânea and BRS Diamantina

\begin{tabular}{lcc}
\hline $\begin{array}{l}\text { Information on } \\
\text { accessions }\end{array}$ & BRS Cipotânea & BRS Diamantina \\
\hline BRA code & 052680 & 064572 \\
Germplasm bank code & MG 075 & MG 053 \\
Collection name & Milho Palha Roxa & Palha Roxa \\
Collection site & Barroso-MG & Carmo de Minas-MG \\
Collection date & $08 / 26 / 1985$ & $11 / 30 / 1988$ \\
Collector & Ronaldo Feldman & Ronaldo Feldman \\
\hline
\end{tabular}

replanted twice in the field, together with the other accessions tested, to obtain enough seeds for the evaluations. Generally, accessions from a germplasm bank, created to preserve the genetic variability, are not exposed to selection (Teixeira et al. 2005). However, in this study the seeds were multiplied with a view to breeding, justifying the use of intrapopulation selection to eliminate tall plants and/or with high ear insertion and late and broken or lodged plants.

\section{Participatory selection}

The selection process for the indication of the varieties BRS Cipotânea and BRS Diamantina began with the evaluation of file data of the Maize Germplasm bank accessions. Firstly, the users of corn straw were visited to compile the properties of husk suited for handicraft. Based on this information, the file cards of the accession collection were read and 50 accessions from the states of Minas Gerais, Bahia, Paraná, Mato Grosso do Sul, and Santa Catarina selected, with properties such as "purple husk" or "soft husk".

After the initial selection, the seeds were multiplied for identification tests of accessions from the Maize Germplasm bank with husk suited for craft. Additionally, traits related to yield and agronomic performance were assessed. Assessments were conducted in an experimental area of Embrapa Maize and Sorghum and in the community of Planalto de Minas in Diamantina and Cipotânea, both in Minas Gerais. The traits were evaluated by extension staff of the Company of Technical Assistance and Rural Extension of Minas Gerais (Emater-MG) and artisans who work with corn husk. The possible forms of participatory breeding and contributions of the farmers and researchers can vary widely (Morris and Bellon 2004). In this study, the participation of the end user, the artisans, was focused on the stages of testing and evaluating the husk quality. The intrapopulation selection, for agronomic traits only, was however not participatory. It is worth mentioning that the evaluation of husk quality is subjective and should therefore be performed by someone familiar with husk properties. It should also be emphasized that the identification of BRS Cipotânea and BRS Diamantina aimed to detect suitable accessions for corn husk craft in the maize germplasm bank, rather than alter the allele frequency of these populations by intrapopulation selection.

The results of the evaluation of the Maize Germplasm bank accessions for corn husk craft were presented by Teixeira et al. (2007).

\section{PERFORMANCE CHARACTERISTICS}

After identifying the best-suited cultivars for corn husk craft, experiments of Value for Cultivation and Use (VCU) were conducted to evaluate the performance of these varieties and for subsequent inclusion in the National Registry of Cultivars of the Ministry of Agriculture, Livestock and Supply.

Nine VCU experiments were carried out, using maize varieties BRS473 and BR106 as controls (see Table 2 for soil and climatic regions, locations and years of VCU tests). The average coefficient of variation for grain yield in the VCU trials was high (27.36\%), although this point had no influence on the trait studied.

Table 2. Soil-climatic regions, locations and years of VCU evaluations

\begin{tabular}{cccc}
\hline Experiment & $\begin{array}{c}\text { Soil climatic } \\
\text { regions }\end{array}$ & County-State & $\begin{array}{c}\text { Growing } \\
\text { season }\end{array}$ \\
\hline E1 & $\begin{array}{c}\text { Zona da Mata } \\
\text { Vale do } \\
\text { Jequitinhonha }\end{array}$ & $\begin{array}{c}\text { Cipotânea-MG } \\
\text { Diamantina- } \\
\text { MG }\end{array}$ & 2005 \\
E2 & Cerrado & $\begin{array}{c}\text { Sete Lagoas- } \\
\text { MG }\end{array}$ & 2005 \\
E3 & Cerrado & Dourados-MS & 2005 \\
E4 & Zona da Mata & Cipotânea-MG & 2006 \\
E5 & Vale do & Diamantina- & 2006 \\
E6 & Jequitinhonha & MG & \\
& Cerrado & Sete Lagoas- & 2006 \\
E7 & Semi-árido & Janaúba-MG & 2006 \\
E8 & Cerrado & Dourados-MS & 2006 \\
E9 & & &
\end{tabular}

The mean data for agronomic and husk-related traits are presented in Table 3. The results show that the cultivars are late and have tall plants with high ear insertion, but have long ears, large diameter and are totally husked. The husk color varies among the plants of both varieties. The incidence of ears with pink, purple and mixed husk in BRS 
BRS Cipotânea and BRS Diamantina: maize varieties

Table 3. Mean values for agronomic and corn husk traits of the varieties BRS Cipotânea and BRS Diamantina in the VCU tests

\begin{tabular}{lcc}
\hline Trait & BRS Cipotânea & BRS Diamantina \\
\hline Number of days until male flowering & 77.5 & 76.9 \\
Number of days until female flowering & 80.9 & 80.4 \\
Plant height (m) & 2.93 & 2.87 \\
Ear height (m) & 1.90 & 1.77 \\
Mean length of husked ears (cm) & 25.94 & 25.62 \\
Mean diameter of husked ears (mm) & 43.70 & 39.15 \\
Number of grain rows (greatest frequency) & 14 & 14 \\
Grain texture & Flint & Flint \\
Grain color & Orange & Orange \\
Husk cover of the ear & Complete & Complete \\
1000 seed weight (g) & 316.50 & 270.86 \\
Hectoliter weight (g) & 746.31 & 799.04 \\
Husk color* & pink purple and mixed & purple and mixed \\
Disadvantage of the cultivar & High percentage of lodged or broken plants & High percentage of lodged or broken plants
\end{tabular}

* high incidence of ears with husk in the above colors.

Cipotânea and of ears with purple and mixed husk in BRS Diamantina was high. A comparison of the two varieties showed that the husk of BRS Diamantina is more pigmented than of BRS Cipotânea. The greatest drawback of both varieties is possibly the high percentage of lodged and/or broken plants.

The results of evaluations of the varieties BRS Cipotânea and BRS Diamantina in relation to productivity are presented in Table 4. Interestingly in most trials, the controls were more productive than the varieties suited for corn husk craft. The percentage reductions in grain yield ranged from $2.91 \%$ for BRS Diamantina E5 to $69.96 \%$ for BRS Diamantina in E3 in comparison with the bestperforming control, indicating a highly variable yield performance of these cultivars. It must be remembered that traits of husk quality and not of grain yield in weight or volume were evaluated here, and that the latter is possibly correlated with ear yield.

The development of the varieties BRS Cipotânea and BRS Diamantina could amplify the genetic base of plants suitable for cultivation and the exploitation of the Ex situ Maize Germplasmbank.

\section{BASIC SEED PRODUCTION}

The genetic and basic seed of BRS Cipotânea and BRS Diamantina was produced on isolated plots of Embrapa Maize and Sorghum. Small samples of these seeds will be distributed free of charge to small farmers and communities that need husk for crafts. The varieties were
Table 4. Mean grain yield (in $\mathrm{kg} \mathrm{ha}^{-1}$ ) of the varieties BRS Cipotânea and BRS Diamantina and of the controls in the VCU tests

\begin{tabular}{ccccr}
\hline Trial & $\begin{array}{c}\text { BRS } \\
\text { Cipotânea }\end{array}$ & $\begin{array}{c}\text { BRS } \\
\text { Diamantina }\end{array}$ & BR106 & BRS473 \\
\cline { 1 - 3 } E1 & 5281 & 5134 & 6320 & 6089 \\
E2 & 6456 & 5123 & 5858 & 4790 \\
E3 & 3371 & 1591 & 5298 & 4790 \\
E4 & 2668 & 2937 & 3925 & 3566 \\
E5 & 2657 & 2968 & 3057 & 810 \\
E6 & 1877 & 1097 & 2209 & 1577 \\
E7 & 4375 & 4110 & 7043 & 5110 \\
E8 & 718 & 582 & 1370 & 966 \\
E9 & 1187 & 1176 & 2328 & 2406 \\
\hline
\end{tabular}

tested and can be recommended in the valley of Jequitinhonha and in the Cerrado. Contact address of the Consumer Service Center of Embrapa Maize and Sorghum: sac@ cnpms.embrapa.br.

\section{ACKNOWLEDGEMENTS}

The authors wish to thank the Instituto Centro de Capacitação e Apoio ao Empreendedor - CAPE (support organization for entrepreneurs), the Brazilian Ministry of Agrarian Development and the Ministry of Science and Technology for funding the project.

They are also indebted to the Empresa de Assistência Técnica e Extensão Rural de Minas Gerais - EMATER-MG (institution of rural extension services), the artisans of Planalto de Minas in Diamantina, MG and the artisans of Cipotânea, MG for their help with the tests and assessments. 
FF Teixeira et al.

\section{BRS Cipotânea e BRS Diamantina: variedades de milho}

RESUMO - As cultivares de milho BRS Cipotânea e BRS Diamantina foram desenvolvidas pela Embrapa Milho e Sorgo a partir de acessos do Banco de Germoplasma de Milho. A avaliação foi participativa. Essas variedades foram desenvolvidas visando disponibilizar aos agricultores variedades de milho com palha apropriada para o uso artesanal.

Palavras-chave: artesanato, palha, Zea mays, melhoramento participativo, agricultura familiar.

\section{REFERENCES}

CONAB (2010) Produção de grãos atinge recorde de 146 milhões t. Available at <www.conab.gov.br/conabweb/index.php?PAG= $73 \& N S N=1282>$ Accessed on May 9, 2010.

Morris ML and Bellon MR (2004) Participatory plant breeding research: opportunities and challenges for the international crop improvement system. Euphytica 136: 21-25.

Pacheco CAP, Santos MX, Cruz CD, Parentoni SN, Guimarães PEO, Gama EEG, Silva AE, Carvalho HWL and Vieira Júnior PA (2002) Inbreeding depression of 28 maize elite open pollinated varieties. Genetic and Molecular Biology 2: 345354 .
Ramalho MAP, Silva GS and Dias LAS (2009) Genetic plant improvement and climate changes. Crop Breeding and Applied Biotechnology 9: 189-195.

Teixeira FF, Vasconcellos JH, Andrade RV, Santos MX, Netto DAM, Novotny EH and Monteiro MAR (2007). Desempenho de variedades de milho quanto a qualidade da palha para artesanato. Revista Brasileira de Milho e Sorgo 6: 84-94.

Teixeira FF, Souza BO, Andrade RV and Padilha L (2005) Boas práticas na manutenção de germoplasma de variedades crioulas de milho. Embrapa Milho e Sorgo, Sete Lagoas,. 8p. (Comunicado Técnico 113). 